\title{
Memòria mítica
}

Josep Ramon Jové

Recordo una vella conversa amb el Pere Rovira. En aquella època l'Esther i jo teníem una casa en un paratge perdut de la Segarra i el Pere i la Celina havien vingut a passar el dia amb nosaltres. Era primavera i passejàvem per uns camps que s'oferien esponerosos a la nostra mirada gràcies a les pluges abundants de l'hivern. Com el clima acompanyava i no hi havia pressa per tornar, ens vam possar a xerrar de seguida. Vaig ser jo qui, segurament pel fet que sóc més jove que el Pere, li vaig preguntar si pensava que amb el pas del temps la memòria fa el necessari per transformar en mítiques algunes seqüències de la nostra vida. Crec que endinsar-se en els records pot fer que determinats moments intensos del passat passin per un procés que no sabria explicar i que els acaba "literaturitzant", i m'encuriosia saber que en pensava d'aquesta idea el meu amic escriptor. A la seva manera va estar d'acord amb mi. També, i en aquest cas sense necessitat de dir-nos-ho amb paraules, sé que en aquell instant tots dos vam pensar que, a més de l'amistat, era la música qui donava consistència a molts dels millors episodis d'un passat, ara esdevingut mític, que la vida ens havia permès viure en comú.

Han passat més de dues dècades i el carrer Ballester ha perdut bona part de l'aspecte que tenia durant els anys que va ser l'epicentre del jazz a Lleida. Va ser en aquest carrer que vaig conèixer el Pere fa molts anys. Ara, quan de tant en tant el trepitjo per creuar des de la Rambla d'Aragó al centre comercial de la ciutat, m'envaeix la temptació d'aturar-me davant l'edifici abandonat que fa trenta anys va ser la Sala Europa. Si ho faig, una mena de boira animada que reflexa imatges de músics històrics i dits recorrent instruments, de mirades relaxades per l'efecte de la música i gots mig buits de whisky, cervesa o ginebra, s'instal.la al meu cap com si fos el fum d'una cigarreta que torna d'un temps remot i inoblidable, d'un lloc on el Pere sempre és present perquè allà res tindría sentit si ell no hi fos. Van ser moltes, moltíssimes nits de jazz que després dels concerts s'allargaven fins al matí en un intent, possiblement inconscient, de fer durar al màxim 
el discurs lliure, amable i també amarg que aquella música ens feia arribar. A les nits de l'Europa el jazz no amagava cap de les seves cares, la música no tenia cap vergonya de mostrar la seva evident controvèrsia. Com la situació de la nostra taula era immillorable, centrada a la sala i prop de l'escenari, sempre gaudiam d'una escolta amb bona acústica i excel.lent visibilitat. Hi seiem disposats a gaudir de cada concert, ben proveïts de tabac i beguda. Sovint desviàvem la mirada cap a la dreta, al lloc on un altre amic seia fent-se càrrec de la taula de so. Era el Tonet, propietari del local i veritable pioner en promoure concerts de jazz a la ciutat. Quan les mirades de tots tres es trobaven sabíem que estàvem totalment d'acord. Era un moment grandiós: allò que sonava a l'escenari ens semblava música eterna, lliure, intemporal i nova. Tot el que nosaltres defensavem que havia de ser el jazz i possiblement la vida!

La música ha estat l'objecte de moltes de les nostres converses. M'agrada escoltar al Pere lloant un disc de jazz antic o desemmascarant la farsa d'un artista mediocre. Crec que la seva forma d'exercir la crítica vers qualsevol disciplina artística és el fidel reflex de la seva forta personalitat: sap utilitzar amb mestria una combinació d'intel.ligència, astúcia, humor i ironía que el situa amb facilitat al centre de les tertúlies. El resultat acaba impossibilitant la indiferència sobre l'objecte d'opinió, sigui aquesta bona o dolenta. Per aquestes raons i moltes més sovint penso en ell com en un home del Renaixement sobreviscut fins als nostres dies, un escriptor d'indubtable alçada que manté intacte el nivell quan es tracta d'exercir l'opinió a través de l'escriptura.

Junts, en una d'aquelles vetllades de la Sala Europa, vam inventar Paraula de Jazz, l'espectacle que fusionava la música i els versos i amb el que vam trepitjar dotzenes de ciutats i escenaris. Cadascun d'aquells viatges i concerts podrien generar una collita generosa d'intenses vivències, metàfores potencials sobre els moments impagables que veuen l'art i la vida anar del bracet per les nostres biografies. Per tot això, quan m'aturo a pensar en aquells elements que donarien consitència a la meva memòria mítica, entenc que el Pere Rovira és un dels seus habitants més destacats, estimats i indispensables.

(La Pobla de Cérvoles, gener 2019) 